\title{
OVERVIEW OF BATTERY USAGE IN NASA/GSFC LEO AND GEO SPACECRAFTS
}

\author{
Thomas $Y . Y i$ \\ NASA Goddard Space Flight Center \\ Greenbelt, Maryland 20771
}

A survey of the batteries used in the LEO and GEO missions at the Goddard Space Flight Center is described. For each spacecraft, tentative launch date is given, along with relevant battery parameters including battery size and description, depth-of-discharge, predicted mission temperature, and life requirement.

\section{INTRODUCTION}

The Goddard Space Flight Center (GSFC) has a role to expand human knowledge of the Earth, its environment, the solar system, and the universe. And as such, the Center has been at the forefront of space research and exploration through a myriad of spacecrafts, both low Earth orbiting (LEO) and geosynchronous Earth orbiting (GEO) vehicles. A number of these satellites are listed in Table 1 which shows the relevant battery paramters associated with each spacecraft. All the spacecrafts listed in the table have baselined the nickel-cadmium batteries. All the cells used in these batteries are manufactured by Gates Aerospace Batteries (GAB) in Gainesville, Florida.

\section{BATTERY USAGE}

In July 1989, Cosmic Background Explorer (COBE) will be launched on a Delta rocket from the Western Test Range. COBE is an in-house program to study the big-bang theory. COBE was originally scheduled for a shuttle launch and it was designed with two 50Ah NASA Standard batteries containing 22 cells per battery. However the launch vehicle was changed to a Delta rocket, and the whole spacecraft was redesigned to fit this vehicle. The battery design was changed to a modified 20Ah NASA Standard battery, 18 cells per battery. The battery usage profile is benign. The mission requirement is for 1 year of battery usage with a predicted mission depth-of-discharge (DOD) of 0 to $24 \%$ over one 63 -day eclipse season. The batteries will be subjected to a temperature range of 16 to $22^{\circ} \mathrm{C}$. McDonnel-Douglas Company is the prime for the batteries.

The next GSFC spacecraft to be launched is National Oceanic and Atmospheric Administration satellite (NOAA-D) in December 1989 for weather observation purposes. This spacecraft is among a series of NOAA weather satellites which GSFC is cooperating with the National Oceanic and Atmospheric Administration on. NOAA-D is in a LEO/Polar morning orbit with a predicted mission DOD of 0 to $16 \%$. There are two $26.5 \mathrm{Ah}$ batteries in the spacecraft, 17 cells per battery. The mission duration is 2 years with predicted mission temperature of $5^{\circ} \mathrm{C}$. The next spacecraft, NOAA-I, is scheduled to be launched in May 1989. NOAA-I will operate in a LEO/Polar afternoon orbit with $18 \% \mathrm{DOD}, 5^{\circ} \mathrm{C}$ predicted mission temperature, and 2 year mission duration. It will have three 26.5Ah batteries, 17 cells per battery. NOAA-J is planned for July 1992 launch, and NOAA-K, November 1993. The batteries planned for the NOAA-K, L, and M spacecrafts will utilize the GAB lightweight $50 \mathrm{Ah}$ NiCd design with salient characteristics of the NASA Standard cell. General Electric-Astro, East Windsor is the prime contractor for NOAA satellites. 
After NOAA-D, Gamma Ray Observatory (GRO) will be launched from STS 37 in April 1990. The primary objective of the satellite is to study the gamma ray radiation phenomenon. The spacecraft is in a LEO orbit with predicted mission DOD of $15 \%$ at $15^{\circ} \mathrm{C}$. The battery requirement is for 2.5 years of operation. There are six NASA Standard 50Ah batteries in GRO, 22 cells per battery. These batteries are part of two modular power systems (MPS) made by McDonnel-Douglas Company, each MPS containing 3 batteries.

In July 1990, the first of the second generation Geostationary Operational Environmental Satellite (GOES) will be launched for weather observation purposes. This satellite, GOES-I, is in a GEO orbit with battery parameters of $60 \% \mathrm{DOD}, 7^{\circ} \mathrm{C}$ average temperature, and 5 years life requirement. There are two 12Ah batteries in the spacecraft, 28 cells per battery. The remaining GOES have the same battery parameters. GOES-J is scheduled for November 1991 launch, and GOES-K, May 1992 launch. The launch dates for GOES-L and GOES-M have not been finalized. Ford Aerospace and Communications Company is the prime for GOES.

The last GSFC satellite scheduled for launch in 1990 is the Tracking and Data Relay Satellite (TDRS) in December 1990. TDRS-E will be launched to a GEO orbit for communication purposes. The spacecraft will contain three 40Ah batteries, 24 cells per battery. Relevant battery parameters include the predicted mission DOD of $50 \%$, mission temperature of $5^{\circ} \mathrm{C}$, and duration of 10 years. The next satellite, TDRS-F is scheduled for December 1992 launch, and TDRS-G, May 1994. The next generation of TDRS will probably utilize other cell designs such as advanced $\mathrm{NiCd}$ or $\mathrm{NiH}_{2}$ instead of the existing NiCd design. TRW is the prime for present generation of TDRS.

In August 1991, the first of the GSFC explorer platform satellites will be launched. Extreme Ultraviolet Explorer (EUVE), which is in a LEO regime, will have one MPS which contains three NASA Standard 50Ah batteries. The batteries will be subjected to a predicted mission DOD of $15 \%$, temperature of $15^{\circ} \mathrm{C}$, and life of 3 years.

Upper Atmosphere Research Satellite (UARS) is planned to be launched from STS 50 in December 1991 to study the Earth's ozone layer and other environmental concerns. This spacecraft is in a $56^{\circ}$ inclination LEO. Like EUVE, UARS contains one MPS. The predicted mission DOD is 0 to $24 \%$, temperature, 10 to $16^{\circ} \mathrm{C}$, and mission duration, 3 years.

In addition to these missions, the GSFC has a number of Small Explorer satellites which will be launched from Scout rockets. Battery requirements for these spacecrafts have not yet been finalized. 
TABLE 1. - OUTLINE OF GSFC MISSIONS AND ASSOCIATED BATTERY PARAMETERS

\begin{tabular}{|c|c|c|c|}
\hline MISSION & LAUNCH & BATTERY & ORBIT \\
\hline COBE & $7 / 89$ & $\begin{array}{l}220 \text { Ah Batteries } \\
18 \text { Cells/Battery }\end{array}$ & $\begin{array}{l}\text { LEO/Polar } \\
0-24 \% \text { DOD, 63-day Eclipse } \\
1 \text { Year Mission } \\
16-22^{\circ} \mathrm{C} \\
\end{array}$ \\
\hline NOAA-D & $12 / 89$ & $\begin{array}{l}226.5 \mathrm{Ah} \text { Batteries } \\
17 \text { Cells/Battery }\end{array}$ & $\begin{array}{l}\text { LEO/Polar Morning } \\
0-24 \% \text { DOD } \\
2 \text { Year Mission } \\
5^{\circ} \mathrm{C} \\
\end{array}$ \\
\hline GRO & $4 / 90$ & $\begin{array}{l}650 \text { Ah Batteries } \\
22 \text { Cells/Battery }\end{array}$ & $\begin{array}{l}\text { LEO } \\
15 \% \text { DOD } \\
2.5 \text { Year Mission } \\
15^{\circ} \mathrm{C} \\
\end{array}$ \\
\hline $\begin{array}{l}\text { GOES-I } \\
\text { GOES-J } \\
\text { GOES-K }\end{array}$ & $\begin{array}{l}5 / 90 \\
11 / 91 \\
5 / 92\end{array}$ & $\begin{array}{l}212 \text { Ah Batteries } \\
28 \text { Cells/Battery }\end{array}$ & $\begin{array}{l}\text { GEO } \\
60 \% \text { DOD } \\
5 \text { Year Mission } \\
7^{\circ} \mathrm{C} \\
\end{array}$ \\
\hline $\begin{array}{l}\text { TDRS-E } \\
\text { TDRS-F } \\
\text { TDRS-G }\end{array}$ & $\begin{array}{l}12 / 90 \\
12 / 92 \\
5 / 94\end{array}$ & $\begin{array}{l}340 \text { Ah Batteries } \\
24 \text { Cells/Battery }\end{array}$ & $\begin{array}{l}\text { GEO } \\
50 \% \text { DOD } \\
10 \text { Year Mission } \\
5^{\circ} \mathrm{C} \\
\end{array}$ \\
\hline NOAA-I & $5 / 91$ & $\begin{array}{l}326.5 \text { Ah Batteries } \\
17 \text { Cells/Battery }\end{array}$ & $\begin{array}{l}\text { LEO/Polar Afternoon } \\
18 \% \text { DOD } \\
2 \text { Year Mission } \\
5^{\circ} \mathrm{C}\end{array}$ \\
\hline EUVE & $8 / 91$ & $\begin{array}{l}350 \text { Ah Batteries } \\
22 \text { Cells/Battery }\end{array}$ & $\begin{array}{l}\text { LEO } \\
15 \% \text { DOD } \\
3 \text { Year Mission } \\
15^{\circ} \mathrm{C} \\
\end{array}$ \\
\hline UARS & $12 / 91$ & $\begin{array}{l}350 \text { Ah Batteries } \\
22 \text { Cells/Battery }\end{array}$ & $\begin{array}{l}\text { LEO, } 56^{\circ} \text { Inclination } \\
0-24 \% \text { DOD } \\
3 \text { Year Mission } \\
10-16^{\circ} \mathrm{C} \\
\end{array}$ \\
\hline
\end{tabular}


